\title{
Synergies across the natural resources management fields in Southern Africa: Disaster Risk Reduction and One Health
}

\begin{tabular}{|c|c|}
\hline \multicolumn{2}{|c|}{$\begin{array}{l}\text { Authors: } \\
\text { Clara Bocchino }^{1} \\
\text { Richard Burroughs }^{2}\end{array}$} \\
\hline $\begin{array}{l}\text { Affiliations: } \\
{ }^{1} \text { Faculty of La } \\
\text { University, So }\end{array}$ & $\begin{array}{l}\text { v, North West } \\
\text { th Africa }\end{array}$ \\
\hline \multicolumn{2}{|c|}{$\begin{array}{l}{ }^{2} \text { Centre for Veterinary } \\
\text { Wildlife Studies, Faculty } \\
\text { of Veterinary Science, } \\
\text { University of Pretoria, } \\
\text { South Africa }\end{array}$} \\
\hline \multicolumn{2}{|c|}{$\begin{array}{l}\text { Correspondence to: } \\
\text { Clara Bocchino }\end{array}$} \\
\hline \multicolumn{2}{|c|}{$\begin{array}{l}\text { Email: } \\
\text { clara.bocchino@gmail.com }\end{array}$} \\
\hline \multicolumn{2}{|c|}{$\begin{array}{l}\text { Postal address: } \\
\text { Private Bag X6001, } \\
\text { Potchefstroom 2520, } \\
\text { South Africa }\end{array}$} \\
\hline \multicolumn{2}{|c|}{$\begin{array}{l}\text { Received: } 18 \text { July } 2012 \\
\text { Accepted: } 12 \text { Oct. } 2012 \\
\text { Published: } 22 \text { Feb. } 2013\end{array}$} \\
\hline \multicolumn{2}{|c|}{$\begin{array}{l}\text { How to cite this article: } \\
\text { Bocchino, C. \& Burroughs, } \\
\text { R., 2013, 'Synergies across } \\
\text { the natural resources } \\
\text { management fields in } \\
\text { Southern Africa: Disaster Risk } \\
\text { Reduction and One Health', } \\
\text { Jàmbá: Journal of Disaster } \\
\text { Risk Studies 5(2), Art. \#74, } \\
10 \text { pages. http://dx.doi.org/ } \\
10.4102 / \text { jamba.v5i2.74 }\end{array}$} \\
\hline \multicolumn{2}{|c|}{$\begin{array}{l}\text { Note: } \\
\text { 1st Biennial Conference, } \\
\text { Southern African Society for } \\
\text { Disaster Reduction (SASDiR), } \\
09 \text { to } 11 \text { October 2012, } \\
\text { Potchefstroom, South Africa. }\end{array}$} \\
\hline \multicolumn{2}{|c|}{$\begin{array}{l}\text { Copyright: } \\
\text { C 2013. The Authors. } \\
\text { Licensee: AOSIS } \\
\text { OpenJournals. This work } \\
\text { is licensed under the } \\
\text { Creative Commons } \\
\text { Attribution License. }\end{array}$} \\
\hline Read online: & \\
\hline 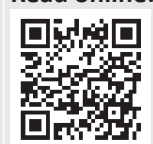 & $\begin{array}{l}\text { Scan this QR } \\
\text { code with your } \\
\text { smart phone or } \\
\text { mobile device } \\
\text { to read online. }\end{array}$ \\
\hline
\end{tabular}

Authors:

ara Bocching

\section{Affiliations:}

${ }^{1}$ Faculty of Law, North West

${ }^{2}$ Centre for Veterinary Wildlife Studies, Faculty of Veterinary Science, University of Pretoria South Africa

\section{Correspondence to: \\ Email:}

Postal address:

Private Bag X6001

Potchefstroom 2520,

Dates:

Received: 18 July 201

Accepted: 12 Oct. 2012

How to cite this article: Bocchino, C. \& Burroughs, R., 2013, 'Synergies acros the natural resources management fields in thern Africa: Disaster Risk Jàmbá: Journal of Disaster Risk Studies 5(2), Art. \#74 10 pages. http://dx.doi.org/

Note:

Southern African Society for Disaster Reduction (SASDiR) 09 to 11 October 2012,

Copyright:

is licensed under th

Creative Commons

Attribution License.
For various reasons, Southern Africa may be considered the playground as well as the thinking tank for many theories and practices in the natural resources management field. History has contributed to reshape conservation practices through colonial times, and recent wars have led to the relocation of people from their homelands and the appropriation by people of previously protected areas due to socio-economic pressures. Contemporary practices stemming from sustainable development have not yielded the expected results in resolving critical socio-economic stresses that impact on environmental health. Furthermore, human health has deteriorated in remote rural areas due to the failures of governance systems and the perpetration of non-participatory models for natural resources management, especially conservation. This paper seeks to explore how two relatively new approaches, Disaster Risk Reduction and One Health, can together tap into the theoretical and practical gaps left by previous paradigms in order to instill a sustainable development approach that can benefit both people and natural resources in remote and poor rural areas.

\section{Introduction}

Southern Africa may be considered the playground, as well as thinking tank, for many theories and practices in the natural resources management field. From the adaptation to natural cycles of the African populations to the intervention of colonial governments and to the experimentation in alternative conservation with adaptive management and community-based natural resources management, the past century has witnessed changes affecting the way people perceive and relate to the environment and its resources. The results have varied from the success stories of Namibia and pre-2001 Zimbabwe, to the maintenance of fortress conservation principles in South Africa. Recent history has contributed to re-shape conservation practices as segregationist and secularist regimes led to the relocation of people from their homelands and the appropriation by people of previously protected areas due to socio-economic pressures. Despite the recent changes, triggered by the international paradigm of sustainable development and environmental management, the problem remains of environmental degradation in areas of limited carrying capacity due to climate and human density, which ranges from water pollution and unsustainable water uses in water-scarce areas to illegal hunting for local consumption and trade, and poor or non-existent land-use planning. In areas where people are settled close to protected areas, human-wildlife conflict is not limited to crop raiding and destruction. It extends to the socioeconomic realisation that conservation is to the benefit not of local people, often dispossessed by colonial and independentist regimes (Zimbabwe and South Africa), but of the others: the wealthy urbanites who live far away from the problems locals face.

The perpetration of such conflicts is visible in the way conservation paradigms struggle to adapt, as well as in the way poor governance impedes socio-economic development, including health, education and participation. This paper seeks to explore how two relatively new approaches, Disaster Risk Reduction and One Health, can together tap into the theoretical and practical gaps left by previous paradigms in order to instill a sustainable development approach that can benefit both people and natural resources in remote and poor rural areas.

\section{The Southern African evolution of Natural Resources Management theories}

The conservation of natural resources in Africa has, understandably, always had a utilitarian aim: natural resources had to support local populations in striving for survival in a continent prone to cycles of drought and disease. It was only with the establishment of the European colonies and the introduction of Western protectionist theories that conservation - intended to protect the natural environment and its desirable species, excluding predators - became driven by aesthetic values, 
with perhaps the exception of forests, which were needed to supply wood for civil construction locally and abroad (Anderson 1987; Hughes 1987; Turton 1987).

Aesthetic conservation values, unaffordable and nonsensical for African people, resulted in the degeneration of the relationship between Africans, the colonial governments and the wilderness (considered by Africans as the areas inhabited by wildlife). Thus, in order to accommodate conservation, there was a progressive erosion of people's rights to land, forestry, water, grazing and subsistence agriculture. Traditional land tenure and land uses were dismissed as being in conflict with the colonial conservation vision: to maintain wild Africa as the hunting ground for Europeans fulfilling romantic perceptions in their mother lands (Bell 1987; Büsher \& Dietz 2005).

The grounds for conservation during the early colonial period became the theoretical foundations for the 'fortress conservation' approach of the 1950s and 1960s (Büsher \& Dietz 2005). This approach has shaped the relationship between Africans, wildlife and law enforcement over the past two centuries, and is still influential in the current state of affairs.

Firstly, one must note that the wildness, which was found by Europeans in Africa and which enchanted them to the point of mythicising it and wanting to protect it, had previously been managed by the African communities which inhabited its surroundings, as well as by natural processes including climate, and particularly nomadic pastoralists. This is often forgotten in current policy making, in the same way that it was forgotten in the implementation strategies of the colonial period. Historical sources show a growing mistrust by colonial administrators and later governments in the ability of agropastoralists to continue traditional management systems, despite their demonstrated ability to manage rangeland in precolonial times. This failure to realise that there can be a balance between using nature and preserving its systems and resources arises from a dichotomous view of the conservation of natural resources: aesthetic for western culture versus utilitarian for rural Africans. Neither is better, and both can work only under other related conditions. These conditions stem from the acknowledgement of historical events and politico-economic decision-making (such as segregation) are to be treated as slow onset hazards, which are reaching their climax. Once this is done, as advocated by modern Sustainable Use approaches and as explained later in the paper, continuous negotiation and adaptive management processes will contribute to merge to superficially contrasting views on natural resources.

Furthermore, regardless of the approach that one uses to conserve nature, it is intrinsically logical that a degree of management is required once a portion of land is enclosed by any means. Whether or not the management is supporting utilitarian needs, it can no longer be treated as a natural system. The carrying capacity of that land changes, as does the interrelation of all its components. By setting aside areas for conservation, in effect, the colonial governments had parcelled off existing ecological rangeland systems supporting both natural and human systems - even the nomadic pastoralists, who were later demonised. Similarly, it is simplistic to use the environmental degradation argument to exclude rural communities from conservation. In acknowledging the environmental impact of processes such as the Bantustans in South Africa or the Native Reserves in Zimbabwe and Kenya, one should still bear in mind that people reproduce and, regardless of the rate at which this happens, if the space allocated to them does not increase, the environment will become increasingly degraded. This is reflected in land use practices, as well as the harvesting of natural resources (firewood, Mopani worms, fruits, etc.) and livestock grazing.

Finally, despite the general refusal of Western conservation paradigms to promote any utilitarian use of protected areas, indirect benefits have been sought particularly in politics and national security. Conservation areas have served many purposes, mostly economic, political and strategic. The point has been made before that, regionally, the presence of protected areas along national borders has also served the purpose of creating buffer zones between states, as well as between ethnic groups that were representing a threat to the status quo. In looking at the history of the Kruger National Park, for instance, it was funded to allow for the preservation of indigenous species, although its management included the extermination of predators, and its extensions were originally motivated by the conservation strategies of its warden Stevenson Hamilton (Carruthers 1995). It later served the purpose of a buffer zone against Mozambique during the regional conflicts since the 1970s. The inclusion of the Makuleke portion, in particular, was determined by political and strategic defence goals, rather than by environmental concerns. The overall aim of government was to protect its borders from the incursions of anti-establishment movements from Mozambique and Zimbabwe, which would have contributed to fuelling the South African situation at that time (Bocchino 2008).

Fortress conservation, founded on the premise that Africans have harmed their environment, was enforced by colonial governments first and Southern African independence governments later, to protect European aesthetic values of the African wilderness. Specific groups of people such as rural African communities were forced to live on the borders of the protected areas, and excluded from enjoyment of the area or potential financial benefits (Brockington 2002). During the 1980s, however, a group of lateral thinkers provided the theoretical inputs for shifting conservation practice towards a more inclusive paradigm that would allow rural communities to participate in conservation, whilst maintaining their traditional livelihoods.

What Bell named 'conservation with a human face' (Bell 1987:79) was an acknowledgement that previous justifications for African exclusion, i.e. environmental degradation caused by demographics, livelihoods and land use practices, proved invalid a century after such assumptions had been made, thus undermining the very essence of fortress conservation. The stimulus for such an argument was provided by the realisation that conservation is simply one activity in the field of natural resources management (NRM), which has much 
wider scope than conservation. NRM aims at preserving natural systems, which include predators (animal or human), in order to provide benefits to both the environment, by reducing degradation, and to humans, by providing them with a chance to live.

Internationally, NRM was set in the broader sustainable development discourse articulated by the Brundtland Report in 1987 (World Commission on Environment and Development 1987), which advocated a new economic paradigm to be more conscious of its impact on the environment and impoverished societies. NRM, however, espoused a shift in conservation thinking that could put an end to human segregation for natural resources, and allow the creation of new systems aimed at socio-economic development through the sustainable use of natural resources. Founded on the understanding that natural resources, defined as 'common', can be managed by their users without triggering the tragic loss of all resources (Ostrom 1990), NRM evolved in its linkages with rural communities as a tool to strengthen existing local institutions governing the use and ownership of natural resources, and its wider conservation goal, and has been applied in Southern Africa and elsewhere in the developing world.

Community-based natural resources management (CBNRM) was never intended to be a short-term solution or a panacea for development strategies, much like tourism has been for the past twenty years. On the contrary, it was defined as a progressive engagement of communities with very localised aims and objectives: the scale of implementation is local. Reflecting on its application in Southern Africa, Marshall Murphree once said that CBNRM was like Christianity, paraphrasing G.K. Chesterton: 'it has not been tried and found wanting, it has been found difficult and not tried' (Jones 2009). The difficulty arises from various drivers, the most important of which is scale. In order to work, CBNRM has to combine different levels of scale. The success of CBNRM experiences in Zimbabwe and Namibia is the result of a balance between scales, achieved by establishing projects that are solidly grounded on three pillars: benefit, empowerment and conservation (Murphree 2009). These should not be taken lightly, considering that before the fortress conservation theory took over NRM in Africa, rural communities were able to manage natural resources to their own advantage without the environmental degradation that followed exclusion from access to natural resources and settlement segregation. For this reason, Murphree makes a very clear point in drawing conclusions on CBNRM: successful CBNRM projects cannot be replicated, but the means to attain real devolution of ownership of and authority over natural resources for conservation can (Murphree 2009).

The end of the 20th century has witnessed another shift in NRM and/or conservation thinking by increasing the scale of interests to ecosystems, and by focussing on anthropocentric objectives of conservation. Firstly, environmental management (EM) came about in order to address concerns over environmental degradation in western countries through urbanisation and industrialisation. The theoretical background to EM succeded in forcing governments and industries to acknowledge, at least, that the principal cause of environmental degradation is poor management of the environment at any scale, with impacts that transcend terrestrial and maritime borders alike. After the first Earth Summit in Rio in 1992, EM influenced policies and legislation globally in order to reduce and minimise environmental damage. Despite appearing to be a very useful theoretical framework to address both NRM and conservation issues, since it brought together physical and social sciences with one objective - sustainability, EM was not able to influence the conservation field. ${ }^{1}$

The Sustainable use of natural resources (SUNR), instead, directly influenced NRM strategies, particularly CBNRM, because it provided a justification for both: a return to understanding natural resources as (ecosystem) services which people, in general, need to use in order to survive. What will guarantee the conservation of such resources is the sustainability concept: the need to use key natural resources will never end for the human species. Much like EM, SUNR was also brought officially into existence during the Earth Summit with the approval of the Convention on Biological Diversity (CBD). However, the insistence of the CBD on giving biodiversity conservation priority over SUNR does not reflect the needs of developing countries, where conservation per $s e$ is neither socially nor economically sustainable (Southern Africa Sustainable Use Specialist Group 2008). To quote Murphree, conservation is the same thing as sustainability and it entails both biological and human sciences dealing with change; and considering resilience rather than stability' (Murphree 2001, quoted in Southern Africa Sustainable Use Specialist Group 2008:8). Further, SUNR has a declared anthropocentric approach, the key constituency of which is the rural communities who live in or near conservation areas and bear the social and economic costs of humanwildlife conflict without deriving any benefits. Hence, SUNR is 'subsidiary' to sustainable development (Southern Africa Sustainable Use Specialist Group 2008:8), because it shares the same theoretical approach and ultimate goal: to ensure that each generation can live without impairing the rights of future generations. It is unfortunate that SUNR in Southern Africa became too focused on wildlife utilisation, specifically quota hunting, as a short-term revenue-sharing practice that would yield financial benefits to rural communities, and provided little alternative to this.

\section{Critical questions on current regional conservation practice}

Following on from these two trends, conservation in southern Africa has evolved in acronyms and recycled past principles. Biodiversity conservation moved from national parks to transfrontier parks (TPs), from CBNRM to trans-boundary natural resources management (TBNRM): the increase in scale allowed for a reduced vigour in addressing the root causes of conservation failures in a region that is constantly affected by socio-economic, political and environmental hazards. This process of transformation, however, has raised some fundamental questions over past experiences, disciplines and practices.

1.Environmental Management Systems, however, are currently being tested in their adaptation for Protected Areas through the Protected Areas Management Systems Foundations. Their work is still experimental. 
Firstly, the everlasting debate over the general approach to conservation is still looming over practices: should we adopt an ecocentric approach and focus primarily on environmental protection or should we have an anthropocentric approach and acknowledge that ultimately environmental protection serves human more than natural goals?

Regardless of what people percieve their interests to be, anthropocentrism has provided many solutions for natural resources management in Southern Africa because it acknowledges that natural resources are a basic and fundamental component of food security in rural areas. This is not because rural people shy away from modern life-style, but because in the absence of other sustainable livelihood opportunities there is no alternative. Sustainable development, hence CBNRM, SUNR and EM, all share the same anthropocentric view that the environment and its resources will always be needed by humankind to guarantee its survival. To use a very relevant example, the value of a rhinoceros is not necessarily aesthetic: it is quantified in the value of its horn, which is a medicinal resource in the East and a livelihood resource in Africa. Continuing to pursue an aesthetic fortress conservation approach is not only anachronistic, but it will also ensure the extinction of the species it is trying to protect.

Secondly, despite following an anthropocentric approach, what are the objects of any management plan people or nature and its resources?

Since colonial times, all the various permutations of conservation theory in Southern Africa have revolved around the management of Africans, considered the primary cause of environmental degradation. These theories and practicies have effectively managed to exacerbate humanwildlife conflict and condemned those Africans continuing their traditional livelihood patterns as outlaws in a biased system. The exceptions are SUNR and EM, the latter being increasingly less concerned with conservation.

Far from being a superfluous point, this is crucial to finding resource management solutions that can benefit both the environment and people in a sustainable way. Managing people would intrinsically lead to past practices of exclusion, and removal from protected areas and their immediate surrounding would entail alienation from traditional livelihoods without any alternative. It would continue to foster the use of fences to keep people out and not animals in. It would lead to a forced peri-urbanisation consisting of shantytowns, facing the failure of urban planning and basic infrastructure, which is already grossly neglected in remote rural areas. The move, therefore, should be towards EM with a SUNR objective in order to maintain the balance created in protected areas and extend the balance to the buffer zones where human settlements are located.

Thirdly, how can theories, approaches and disciplines coalesce to provide management systems that are flexible and adaptive and based on a local reality whilst maintaining a wider framework?
Transdisciplinarity has been advocated for many years as a possible solution to the various problems generated by the fortress conservation approach. The segregationist and exclusionist approach of fortress conservation has not yielded the same results, once the political systems that initially implemented it changed. Using fences as a management approach forced the acknowledgement that an enclosed space needs to be managed with both standard and ad hoc measures, which may not be acceptable to the general public that supports conservation. Culling is a specific example affecting many protected areas in the region. The number of elephants in protected areas, for instance, increases yearly, but the space available to them is constant: much like human population in the rural areas. This increase in numbers diminishes the carrying capacity of the protected area, hence the delicate man-made balance that is needed to sustain it. It is the same advocates for fortress conservation amongst the non-technical public who become adversaries of the practice itself, due to lack of knowledge and understanding. A transdisciplinary approach, which uses techniques and methods adapted to the local reality, would allow for such problems to be overcome not by enlarging the protected areas - hence potentially increasing human-wildlife conflict - but by finding solutions that benefit humans, the environment, and its wildlife. Having been on the conservation agenda for at least a decade, however, transdiciplinarity in management has proven difficult to achieve in relation to the first point above: the impact of the ecocentric compared to anthropocentric approaches.

Sustainable development was deemed to have provided the answer to these three questions: fundamentally an economic theory considering that natural resources are crucial to human survival and well-being in rural as well as urban areas, worldwide. The critical components for sustainable development, which are reflected in SUNR in so far as conservation is concerned, are: society, economics

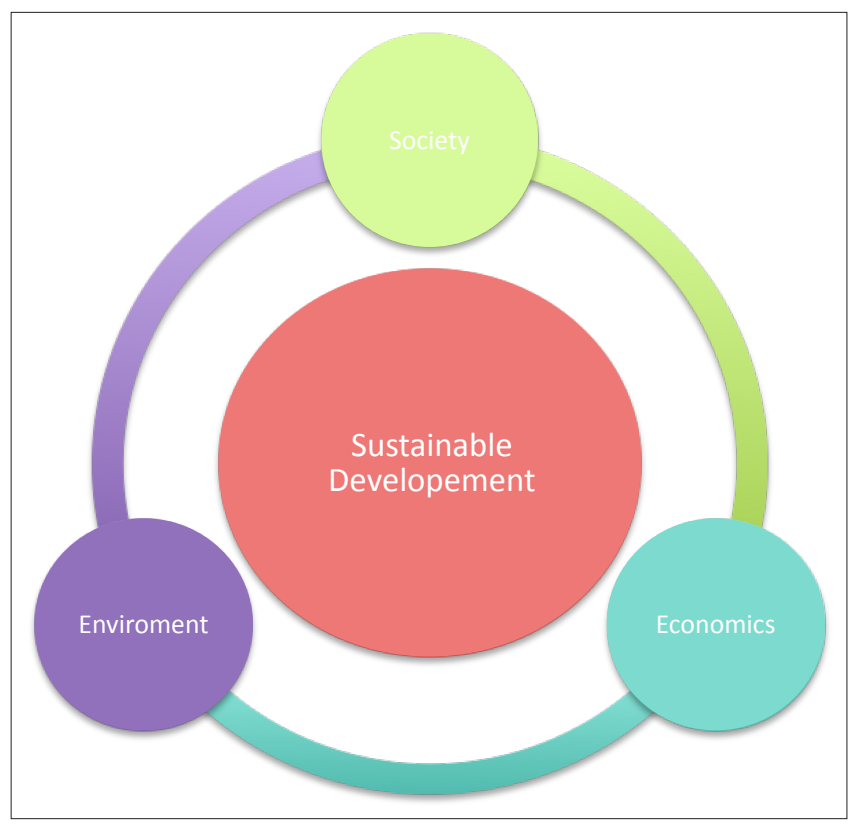

Source: Idealised and designed by Dr Clara Bocchino, 2012

FIGURE 1: Triangulation of elements in Sustainable Development. 
and the environment (see Figure 1). In the implementation of sustainable development, which is a process not an endgoal, the three components must be able to work for each other in order to gain benefits. The basic human need for survival, which can be quantified differently for various categories of people, is the key to understanding this theory and the recommendations of the Brundtland Report (World Commission on Environment and Development 1987). The fundamental question it addresses is - how can the human race feed its need for development without further compromising the quantity and quality of natural resources, from land to water, air and wildlife?

The answer would be through EM, but as far as biodiversity conservation is concerned, NRM provides a better paradigm and, within that, SUNR is the most feasible solution. These alternative conservation approaches have failed in implementation, however, due to the difficulties in combining management with devolution of authority over natural resources at the local level. Clearly, there is no shortterm solution for sustainable development, or for creating viable conservation formats in Southern Africa, nor is there a one-size-fits-all solution.

For this reason, if new theories and practices need to be considered they would have to fall under the sustainable development argument of addressing root causes for long-term processes. They should both be driven by an anthropocentric approach, which would ensure their appreciation in the social, economic and political spheres. They should be compatible to the point of facilitating transdisciplinarity and flexible to adapt to local needs in the understanding that, however similar, no two places, no two peoples are the same.

One Health and disaster risk reduction (DRR) answer these requirements as being both anthropocentric with a focus on SUNR for sustainable development. They are both founded on the understanding that people play an important role in NRM and that most of the working knowledge is already owned by people at the local level, who understand risk, are resilient and know their environment. They both rely on a combination of state intervention (thereby implying that the government is obliged to its commitment to its electorate throughout the country), access to market and partnership with the private sector, and people.

\section{Disaster risk reduction: In search of a theoretical framework}

The study of disasters has developed in various phases since the Second World War, which addressed disasters with associated contextual knowledge. Generally, fatalism was the underlying theme, particularly in as far as less developed countries (LDCs) were concerned, and it was derived from the typical assistance mentality of Western countries combined with the strategic needs imposed by the Cold War (Van Niekerk 2010). Simultaneously, theories were being developed which contemplated the relation between disasters, predictability (risk) and social vulnerability.
In particular, the constructivist trend developed the link between disasters and poverty in LDCs. From here, the connection between disasters and development was quickly made and in the 1980s most theorists agreed that the damage of a disaster was not directly influenced by its size, but was inversely proportional to the resilience of the people in the area affected (Van Niekerk 2010).

This realisation allowed for a paradigm shift from disaster management to risk management in order to prevent, mitigate or reduce disasters. Instrumental in these various steps was the role of the international community. Pre-empted by the critical UN Resolution 42 and/or 169 of 1987, the postCold War era was marked by a determination to establish a definite connection between risk and disaster reduction. The resolution, in fact, proclaimed as 1990 the beginning of the international decade for disaster risk reduction (Van Niekerk 2010). During this period, governments were expected to take serious action in disaster reduction and mitigation, focusing not only on quantitative physical data addressing patterns of disasters, but also on policy changes, bridging knowledge gaps, fostering communication and the establishment of new measures in early warning systems (Van Niekerk 2010).

The focus on risk in disaster studies has been constant in the development of this particular field - from the early acknowledgement that predictability of natural hazard could be a clue in understanding disasters (a physical science approach) to the conceptualisation of resilience in order to address those social, economic and political risks that affect people and their capacity to respond to disasters (a social science approach). For this reason, the link with sustainable development, made by researchers initially, was then followed by the international strategy for disaster reduction (Van Niekerk 2010). The incorporation of both approaches into disaster risk reduction within sustainable development has allowed a more comprehensive agenda and set of activities that include:

- contingency planning

- disaster risk management

- DRR plan

- early warning systems

- environmental impact assessment

- preparedness and prevention

- risk assessment and management.

The vision is to generate a safer world by the end of this century (unfortunately referring to the 20th) and beyond (WCNDR 1994) and in order to do so, ensure that risks and hazards are understood in their complexity, which forms the basis for risk assessment in the complex natural and human systems throughout the planet.

The influence given by sustainable development to both disaster and relief management ensures that there is a practical continuum in development cycles of LCDs, particularly in poverty-stricken areas. Preparedness then incorporated the concept of resilience: the mechanism by which people are able to absorb shock of any kind (UNISDR 2009). 
Further to that, the Yokohama Strategy ensured that a key SD principle, good governance, became crucial in the implementation of DRR by stating that 'each country has the sovereign responsibility to protect its citizens from natural disasters' (Van Niekerk 2010:58).

Although missing a common conceptual framework, the development of DRR practice and the role played by the UNISDR have ensured that this was not a new concept to be added to the melting pot of SD. As it is founded on the Brundtland Report, it can blend with the visions set at the first Earth Summit and it can pursue a series of objectives that are not directly related to disasters but the solutions to which would greatly help disaster preparedness and mitigation, particularly in LDCs. Consequently, the objectives of DRR fit with all the Millenium Development Goals, from poverty eradication to human health and environmental sustainability (health), as acknowledged by, amongst others, the World Bank in several of its reports and toolkits on resilient communities and climate change (see also International Strategy for Disaster Reduction; Actioaid n.d. for a comparative analysis). Eventually, the United Nations passed resolution 58 and/or 214 in 2003, where DRR was unambiguosly linked to the implementation of the Johannesburg Plan approved by the World Summit on Sustainable Development for vulnerability, risk assessment and disaster management (Van Niekerk 2010).

The reason why the link between DRR and SD, as well as SUNR, is so strong must be found in the background of both: they are both anthropocentric, rather socio-centric phoenomena (to paraphrase Van Niekerk 2010:65; Wisner, Gaillard \& Kelman 2012). The reason why DRR is increasingly introduced in policy and practice is because it aims at saving the people on this planet and, in so doing, environmental sustainability becomes a by-product. The same can be said for SD, although it focuses on an economic approach. For this reason, it is no longer acceptable to talk about 'natural disasters', because when the hazard is natural, the result of the event is a disaster only because it affects people and societies. The planet, as we know it, has gone through cataclysmic natural events and has changed and adapted: it has never been destroyed.

The theoretical anthropocentrism of DRR influences its practice and its perception of the world's complex systems. It has borrowed much from CBNRM, EM and SUNR, as well as from disaster management. The key critical elements for the DRR to function reflect this experience, and thus DRR:

- Must be a multi-sectoral effort, top-down and bottom-up, across scales from global to local to individual, and informed by knowledge in the present and short term to centuries past as well as projections into the future.

- Requires outside specialist knowledge from many professions, backgrounds, values and disciplines.

- Requires local knowledge that resides with ordinary people, including marginalised groups, in their homes, settlements, community spaces and work places. (Wisner, Gaillard \& Kelman 2012:1)
Ultimately, it may be argued, the objective of DRR is to build resilient communities of people, characterised by health, education and access to services and resources in land uses that are planned sustainably within socio-economic and political systems that have embraced sustainability and are prepared for human and natural hazards (Wisner, Gaillard \& Kelman 2012).

\section{One Health: Applying the conceptual framework}

The role that diseases play in societies and communities, be they human or animal, is potentially enormous, playing a significant role at a global level, but also at a local level. Many of these affect animals exclusively, some affect people, but zoonoses affect both humans and animals (wild and domestic), with different impacts determined by a number of factors that are related to hosts, pathogen and vectors of transmission, and a number of epidemiological factors affecting either host or disease causing factor.

The environment or ecosystem in which an animal or human disease occurs will have a significant effect on the outcome of the disease. The interrelatedness of these three factors animal health, human health and ecosystem processes - thus forms part of the process of understanding the epidemiology of health in its broadest sense.

The processes involved in both human and animal health are fundamentally the same. This was recognised by Virchow in the late 19th century, who stated, 'between animal and human medicine there is no dividing line, nor should there be. The object is different, but the experience obtained constitutes the basis of all medicine' (Conrad 2009). This approach was first described as 'One Medicine' by Osler, and then later refined into a multi-disciplinary approach as 'One Medicine' by Schwabe in 1984 (Schwabe 1984). As globalisation increases, and as population pressures mount on ever-dwindling resources, the need to adopt a trans-disciplinary approach is vitally important.

In 2004, the Wildlife Conservation Society hosted a symposium entitled 'One World, One Health' expressing the need for a more integrative and collaborative approach to health in general (The World Bank Report 2010). The American Veterinary Medical Association in 2008 passed a resolution recommending the adoption of a unified approach to human and wildlife health, which was defined as 'One Health' (AVMA 2008). This has been incorporated into a number of research, training and development paradigms across both the developed and developing world. The interrelatedness of human, animal and ecosystem health is critical to understanding health as a function of multidisciplinary processes and the interaction between each (Deem 2001). An important premise that must be born in mind is that disease in livestock or animals can have a significant impact on the livelihoods of people dependent on those animals.

Although the concept is health in its various forms, the underlying objective is the promotion of people 'issues' 
directly related to socio-economic development, and food security is a critical driver. At the level of wildlife and domestic animal interaction, there is not much emphasis on stock improvement as a means to boost production and food security - the fundamental role that access to adequate and good quality grazing for stock plays is critical. Maintaining ecosystem processes is vital, as is understanding and monitoring these processes. Attempting to define drivers of disease within a 'One Health' paradigm forms not only a fundamental way of addressing the impacts on human livelihoods in the shortest possible time, but also serves as ways for attempting to predict potential destabilisation and the effect that this has on each of the components - animals, humans and ecosystems or environments. The studies that are performed are often defined as interface studies (Gummow 2010) - the interface between animals, humans and the environment: this implies seeking holistic analysis.

In attempting to understand these forces at play, the One Health concept will typically include veterinary and medical professionals, epidemiologists, ecologists (in the broadest sense), social scientists, economists and agricultural specialists, and probably other disciplines. These will depend on the context and environment in which the input is required. Besides the animals and people themselves, and their various associated or interdependent needs, food and water availability and quality are also critical. For instance, non-infectious health-affecting processes, such as deficiencies or toxins (be they of natural environmental, agro-chemical or of plant origin), are also of huge importance (Gummow 2010). These can play a significant role, not only in the health of animals, leading to signs of toxicity or poor production, but can also have a deleterious effect on people. Sometimes these symptoms in animals show before the onset of signs in people, emphasising the importance of recognising the impact of pollutants on animal health before it is detected in human populations.

This has not always been achieved, in spite of being promoted as a way of making a meaningful contribution to improved livelihoods (The World Bank Report 2010). One Health research or training objectives are, by nature, often promoted or led by veterinarians, with little input from the medical side, in spite of the direct zoonotic link. The closest an integrated approach came to address a health issue was with the spate of influenza epidemics that affected the world in the last 15 to 20 years (The World Bank Report 2010). In their Report of 2010, The World Bank suggested that the approach needed was to move from one of 'what can I do?' to 'what must be done?' - emphasising the multi-disciplinary role that needs to be played in terms of monitoring as well as controlling a disease (The World Bank Report 2010).

Fundamental understanding of disease and its implications depends on sound surveillance of the target populations, and a thorough risk analysis of the potential outcomes of a disease, including the effects not only on the population at risk, but also the impact on human livelihoods, even if they are not directly affected. Understanding the role that wildlife play in this is also key, particularly where they are potential reservoirs for a number of infectious or tick-transmitted diseases. It is estimated that $70 \%$ of all new zoonoses are of wildlife origin (The World Bank Report 2010).

The concept of 'One Health' has been adopted by a number of international standard-setting organisations or enabling organisations, including the OIE, FAO and WHO. It increasingly forms an integral part of both undergraduate and post-graduate veterinary programmes at a number of universities (Deem 2010). It has also been included in many regional programmes (in Africa and elsewhere) that attempt to promote local development of impoverished communities, such as the Wildlife Conservation Society, who have coined the term 'One World One Health'.

\section{Synergies for Natural Resources Management}

In mathematical terms, the relationship between disaster and health is biunique and inversely proportional. The lack, or poor quality, of health exacerbates the magnitude of the disaster, and vice versa. However, it is logical that a higher quality and spread of health services will reduce the impact of a disaster on a given group of people, both on a population and ecosystem level.

The relationship between DRR and One Health is also biunique, yet directly proportional.

Firstly, it is biunique because both disciplines can affect each other and build on each other's practical experiences. Both aim at initiating and maintaining a sustainable process of socio-economic growth with decreasing environmental degradation, which is particularly challenging in LDCs and their rural and peripheral areas. Although having environmental protection, almost as a by-product, they both see a healthy environment as critical to the sustainability of any other processes for human development. Both understand the role that natural hazards, including diseases, play in sidetracking sustainable development components, including human health, animal health, sustainable livelihoods and environmental management.

Secondly, the relationship is directly proportional, because the more one discipline is implemented in a given area, the more the other discipline will also benefit and grow. One Health aims at achieving health in a holistic framework, which incorporates medical, social, economic and environmental health. DRR sees the same holistic health as a basic steppingstone in risk prevention and mitigation, because health increases resilience, which is essential to ensure pre- and post-event sustainable practices. Furthermore, DRR seeks the resolution of health, and more broadly human security issues, as a pre-requisite to implementing any other derived risk-related strategy, including disaster management. 
The existence of a field within DRR dedicated to the "epidemiology of disasters" (Keim \& Abrahams 2012) intrinsically establishes a strong bond between the two disciplines. In their application to remote rural areas in LDCs, this becomes essential in trying to fill the gaps left by previous natural resources management strategies in order to close what can be called the 'sustainability cycle' on a continent where the environment, much like its inhabitants, has undergone major health-related stresses over the past century and is enduring the constant presence of slow-onset natural and anthropogenic hazards.

Risk is the first and most important synergy that DRR and One Health should build upon. In trying to resolve the health and human security question for rural areas, both focus on the identification and understanding of risk through risk assessment and evaluation processes. The similarity of the two approaches is confirmed by the use of comparative methodologies in the planning phase, which aim at understanding a natural and human-environment as a whole, whilst focussing on the interface between hazard and human resilience.

DRR also recognises the specific role of natural hazards and their impact on health, both in determining resilience levels and in post-disaster situations through Health Emergency Management (HEM). This sub-component of DRR encompasses the functions that are needed to prevent, mitigate, respond to and recover from health emergencies and disasters (Keim \& Abrahams 2012). However, it recognises that health is critical in reducing vulnerability of (potentially) affected communities and groups of people.

The concepts of resilience, health and vulnerability represent a second strong synergy between DRR and One Health: both recognise the link between the three elements and their positive impact on ecosystem health, on the one hand, and DRR on the other. Resilience and health, although percieved as similar, describe two very different conditions for humankind. In the DRR terminology, resilience is:

\footnotetext{
... the ability of a system, community or society exposed to hazards to resist, absorb, accommodate to and recover from the effects of a hazard in a timely and efficient manner, including through the preservation and restoration of its essential basic structures and functions. (International Strategy for Disaster Reduction 2009:24)
}

Health is therefore an important component of resilience, but it is not necessarily true that healthy people are, intrinsically, resilient people. Üstün and Jakob (2005) highlighted the need to have a definition of health that could somehow move away from scientific standards, which simply add level of complexity to the definition itself, whilst being less generalist than the one given by the World Health Organization (Üstün \& Jakob 2005). Awofeso is in agreement with this, and although finding limitations in all of them, deems them very important as a means to redefine the current WHO definition (Awofeso 2005). Bircher defines resilience as 'a dynamic state of well-being characterized by a physical and mental potential, which satisfies the demands of life commensurate with age, culture, and personal responsibility' (Bircher 2005; Awofeso 2005:1). Here we see the connection between health and resilience, although the actual description of health escapes the author.

Vulnerability, instead, is strongly connected to the notion of health, because the two are mutually exclusive: the less vulnerable, the healthier, and vice versa. In the DRR jargon, vulnerability is:

The characteristics and circumstances of a community, system or asset that make it susceptible to the damaging effects of a hazard. (International Strategy for Disaster Reduction 2009:30)

Whether in reference to an individual or a group of people, vulnerability assessment includes their state of affairs which, in turn, includes human and environmental and/or animal health. The circumstances, in the definition above, refer to two other points of synergy between DRR and One Health in reference specifically to the rural poor and, in general, the underprivileged: capacity building and access to natural resources.

Far from using the expression in a broader term, capacity building in this context refers specifically to (1) the ability to develop one's full socio-economic and health potential, and (2) the active involvement in the critical processes of risk analysis and assessment, as well as mitigation and warning systems. Both disciplines, in fact, revolve around the roles of community participation in establishing and maintaining supporting systems to improve health and reduce disaster risk, respectively.

Access to natural resources is important for both disciplines in order to improve livelihoods in rural areas, particularly where environmentally degraded communal areas neighbour almost pristine protected areas for ecosystem conservation. The theories of CBNRM and SUNR provide feasible longterm solutions to resolve conflicts in such situations, whereby improved or alternative livelihoods based on natural resources could improve health and reduce health hazards for rural people, as well as increase engagement in DRR. Furthermore, both One Health and DRR understand the need to operate at the interface of risk. Areas with communal lands bordering protected areas, in fact, generate important questions for HEM, recognised under the transmission of disease in the human-livestock-wildlife triangulation, with water being the interface with the highest risk factor (Keim \& Abrahams 2012). In both rural and urban areas, furthermore, it is polluted water from industrial processes and lack of sanitary infrastructure as well as medical and veterinary services in and around settlements that place people in contact with diseases and the risk of pandemics. From a disaster perspective, floods also cause the spread of endemic and new diseases, which affect people and their livelihoods.

\section{Conclusion}

Conservation theories in Southern Africa have evolved since the colonial period to include more participatory approaches, both influencing and being in line with the international 
evolution of sustainable development theory. The practices, however, still rely on fortress conservation principles of fences where a strong interface exists between wildlife and rural communities. This is explained by the need to avoid further environmental degradation due rural livelihoods based on livestock grazing and the harvesting of natural resources, as well as to protect people and livestock from disease contagion.

DRR and One Health are challenging this status quo through holistic and integrated approaches that are founded on sustainable development in a clear anthropocentric perspective. The perception of risk, vulnerability, health, resilience, access to natural resources and capacity building are the critical synergies upon which cooperation between the two synergies may be built. Practically, both approaches can work together from the initial applicative stages with activities aimed at creating a baseline study for intervention. Management practices would then have to incorporate both findings and methodologies in a cooperative framework that involve affected communities, government departments and the private sector at the local scale. Two critical aspects in merging the disciplines form the core for practical implementation.

Risk analysis is to be understood as a critical initial component for change, because it will identify hazards, cluster them and evaluate current strategies for mitigation, avoidance and eradication. Such an analysis would involve a multi-disciplinary team of experts able to focus on the critical drivers (social, economic, political, technological and environmental) and their relative sub-categories. The analysis and assessment of risk may use scenario planning in order to understand drivers and phases required to achieve the objectives.

Locale management is the area of implementation and must be treated as a whole, where different institutions cooperate and land-uses coexist. This is the greatest challenged posed by DRR and One Health, both separately and jointly. Southern Africa countries, despite national constitutions, have proven unable to deliver infrastructure and services in peripheral areas, which has exacerbated the risk of disasters (medical or otherwise). A shift is needed towards the application of good governance principles in the rationale for managing local areas, which are funded in the participatory approaches of EM and SUNR. Furthermore, following the trend set by Transfrontier Conservation Areas, political geography may often prove detrimental to DRR-OH approaches: the recognition of other, less formal, geographies must form the basis of the process. Cultural commons in Southern Africa are often stronger than nationalisms for natural resources management, regardless of the approach, (Bocchino \& Murphree 2012).

It must be borne in mind that the implementation of DRR$\mathrm{OH}$ approaches to the management of a locale share the same risks as CBNRM; failure to recognise them entails failure in achievement. There will never be a set formula for successful implementation, but a localised plan which draws from a variety of lessons learnt from projects that place at their core the role of local people (whether in urban or rural areas, and regardless of the economic status), their needs and their participation.

\section{Acknowledgments Competing interests}

Both authors are expert in the two approaches object of the text. None of the information provided is influenced by professional or personal affiliation to an institution, but it is the outcome of research work conducted in the field of study. The authors declare that they have no financial or personal relationship(s) which may have inappropriately influenced them in writing this paper.

\section{Authors' contributions}

The paper was conceived and written for the most part by C.B. (Faculty of Law, North West University). R.B. (Faculty of Veterinary Science, University of Pretoria) was responsible for writing the One Health section and contributed to the review and finalisation of the paper.

\section{References}

American Veterinary Medical Association (AVMA), 2008, One Health Initiative Task Force: One Health: A New Professional Imperative.

Anderson, D. \& Grove, R. (eds.), 1987, Conservation in Africa: People, policies and practice, vol. 1, Cambridge University Press, Cambridge.

Anderson, D., 1987, 'Managing the forest: The conservation history of Lembus, Kenya, 1904-63', in D. Anderson \& R. Grove (eds.), Conservation in Africa: People, policies and practice, pp. 249-268, Cambridge University Press, Cambridge.

Awofeso, N., 2005, 'Bulletin of the World Health Organization: Re-defining "Health"', World Health Organization, viewed 07 May 2012, from http://www.who.int/ bulletin/bulletin_board/83/ustun11051/en/index.html.

Bell, R.H.I., 1987, 'Conservation with a human face: Conflict and reconciliation in Afrian land use planning', in D. Anderson \& R. Grove (eds.), Conservation in Africa: People, policies and practice, pp. 79-102, Cambridge University Press, Cambridge.

Bircher, J., 2005, 'Towards a dynamic definition of health and disease', Medicine, Healthcare \& Philosophy 8(3), 335-341. http://dx.doi.org/10.1007/s11019-005-0538-y

Bocchino, C., 2008, 'Is Mozambique the new South-African frontier? The socioeconomic impact of the Great Limpopo Transfrontier Conservation Area on the livelihood strategies of border communities in the Pafuri Administrative Post', University of Bologna, Bologna.

Bocchino, C. \& Murphree, M., 2012, 'Overlapping cultural commons and districts in the Great Limpopo Transfrontier Conservation Area: Potentials for local economic development', in E. Bertacchini, G. Bravo, M. Marelli \& W. Santagata (eds.), Cultural commons: A new perspective on the production and evolution of cultures, Edward Elgar Publishing, Cheltenham.

Brockington, D., 2002, Fortress conservation - The preservation of the Mkomazi Game Reserve, (African Issues) Tanzania, vol. 1. 9, The International African Institute in association with James Currey, Mkuki Na Nyota and Indiana University Press.

Büsher, B. \& Ton, D., 2005, 'Conjunctions of Governance: The state and the conservation-development nexus in southern Africa', The Journal of Transdisciplinary Environmental Studies - Special Issue 4(2), 1-15.

Carruthers, J., 1995, The Kruger National Park - A Social and Political History, University of Natal Press, Pietermaritzburg.

Patricia, C., Mazet, J., Scott, D.C.C. \& Wilkes, M., 2009, 'Evolution of a transdisciplinary "One Medicine-One Health" approach to global education at the University of California, Davis', Preventative Veterinary Medicine 92, 268-274. http://dx.doi. org/10.1016/j.prevetmed.2009.09.002

Deem, S., Karesh, W. \& Weismann, W., 2001, Putting theory into practice: Wildlife health in conservation, Conservation Biology 5(15), 1224-1233. http://dx.doi. org/10.1046/j.1523-1739.2001.00336.x

Gummow, B., 2010, Challenges posed by new and emerging infectious diseases in livestock production, wildlife and humans, Livestock Science 130, 41-44. http:// dx.doi.org/10.1016/j.livsci.2010.02.009

Hughes, F., 1987, 'Conflicting uses for forest resources in the Lower Tana River basin of Kenya,' in D. Anderson \& R. Grove (eds.), Conservation in Africa: People, policies and practice, pp. 211-228, Cambridge University Press, Cambridge. 
International Strategy for Disaster Reduction, 2009, UNISDR terminology on Disaster Risk Reduction, UNISDR, Geneva.

Jones, M.A., 2009, 'Trying to make sense of it all: Dealing with the complexities of community-based natural resources management', in B.B. Mukamuri, J.M. Manjengwa \& S. Anstey (eds.), Beyond propietorship: Murphree's laws on community-based natural resources management in southern Africa, pp. 179-197. Weaver Press, Harare.

Keim, Mark., \& Jonathan, Abrahams., 2012, 'Health and disaster', in B. Wisner, J.C. Gaillard \& I. Kelman (eds.), The Routledge handbook of hazards and disaster risk reduction, p. 875, Routledge, London.

Murphree, M.W., 2001, 'Experiments with the future', A seminar on an interdisciplinary longitudinal and interactive methodology to explore environmental and institutiona sustainability in the human use of nature, UCB Botanic Garden, 20 October, University of California Berkeley, Berkeley.

Murphree, M.W., 2009, 'The strategic pillars of communal natural resources management: benefit empowerment and conservation', Biodiversity Conservation 18, 2551-2562. http://dx.doi.org/10.1007/s10531-009-9644-0

Ostrom, E., 1990, Governing the commons - The evolution of institutions for collective action, Cambridge University Press, Cambridge. http://dx.doi.org/10.1017/ CBO9780511807763
Schwabe, C.W., 1984, Veterinary medicine and human health, 3rd edn., Williams and Wilkins, Baltimore.

Southern African Sustainable Use Specialist Group, 2008, 'From sustainable use to sustainable development - Evolving concepts of natural resources management', SASUG Sustainable Develoopment Conceptual Framework, p.46.

The World Bank, 2010, People, pathogens and our planet: Towards a One Health approach to controlling zoonotic diseases, vol. 1, Report 50833.

The World Bank, 2012, People, pathogens and our planet: The economics of One Health, vol. 2, Report 16495

Turton, D., 1987, 'The Mursi and National Park development in the Lower Omo Valley', in D. Anderson \& R. Grove, (eds.), Conservation in Africa: people, policies and practice, pp. 169-186, Cambridge University Press, Cambridge.

Üstün, B.T. \& Robert J., 2005, 'Calling a spade a spade: Meaningful definitions of health conditions', Bulletin of the World Health Organization 83(11), 802-803.

Van Niekerk, D., 2010, A framework for multi-sphere disaster risk reduction: The case of South Africa, Lambert Academic Publishing, Germany.

World Commission on Environment and Development, 1987, Our Common Future, p. 416 United Nations, Oxford Paperbacks, Oxford. 